Cigarette fires

\section{To burn or not to burn: an advocate's report from the field}

\section{A McGuire}

\section{The long campaign for the fire safe cigarette nears its conclusion}

D uring the past two years, three significant events have occurred that will lead to the global reduction of fires caused by cigarettes. First, on 6 May 2003 in a Cleburne, Texas courthouse, the Philip Morris cigarette company ended an eight year products liability case by agreeing to pay damages of \$2 million to Shannon Moore before the case went to a jury. Shannon was 21 months old when she sustained a $77 \%$ burn injury in a fire caused by a Marlboro cigarette. This represents the first "admission" of guilt by a cigarette company after 15 unsuccessful lawsuits filed in the United States during the past 25 years. Second, on 28 June 2004 the first regulation of cigarettes for fire safety took effect in New York state. (In fact, this was the first time cigarettes have ever been subject to product regulation, although labeling, divulging ingredients, toxicity testing, and taxation have been required by different governments at different times.) All cigarettes sold in New York (and, soon, in Vermont) must pass a fire safety test. Finally, in October 2005 Canada, using the New York performance standard, will become the first nation to regulate the fire safety of cigarettes and require that all cigarettes sold in Canada be "fire safe." These three events are the culmination of nearly 30 years of advocacy by numerous individuals and organizations, often laboring in the shadows of the "anti-tobacco" movement. In the realm of injury control, the campaign for fire safe cigarettes provides a case study demonstrating that, in spite of overwhelming corporate opposition, regulating an unsafe product can be successful. Advocates need facts to be on their side, a deep commitment to the public's health, and an abundance of patience.

\section{THE DATA}

Annually, in the United States, cigarettes cause approximately 1000 deaths, over 2000 severe injuries, and close to $\$ 4$ billion in societal costs (property damage, health care, fire service, lost productivity, and so on). Worldwide, cigarettes cause over $10 \%$ of all fire deaths. In groundbreaking research, conducted by the Johns Hopkins University Applied Physics Laboratory between 1971 and 1977, a team of scientists reviewed all fire deaths in concluded that $45 \%$ were caused by cigarettes. This is significant because US fire service generated data (which is the source of federal data) routinely report that, of all fire deaths, the percent of cigarette caused fire deaths is approximately $25 \%$, with an additional $20 \%$ of all fire deaths as "unknown" cause. In general, in the US cigarette caused fire deaths are underreported in national data. Regardless, these data show that the leading causes of fire deaths are cigarette related.

\section{HISTORY OF FIRE SAFE CIGARETTES: 1929-79}

In 1929, a fire in Lowell, Massachusetts was brought to the attention of US Congresswoman Edith Nourse Rogers (D-MA) who, in a now quaint execution of power, "encouraged" the National Bureau of Standards (NBS) to look into developing technology that would render a cigarette, to use the term of the day, "self snubbing". After two years of research the NBS developed a prototype fire safe cigarette. An Associated Press (AP) story reported that the NBS had developed such a cigarette and concluded "Now Dr. Lyman Briggs ... has written Mrs. Rogers that all there is to do is to find a manufacturer to take up the idea".

In a Reader's Digest article in September 1950 entitled "So You Want to Burn to Death!" the California State Fire Marshal is quoted suggesting that cigarette manufacturers could render cigarettes "self extinguishing" as a way to prevent fires. The fire marshal went on to claim that cigarette companies keep cigarettes burning to increase sales of cigarettes. No scientific evidence was presented to back up the fire marshal's claim.

The next media reference to fire safe cigarettes was another AP story in 1974. It cited the US Senate approval of a bill, authored by Senator Hart (D-MI), that the state of Maryland $(n=530)$ and would require cigarettes to self extinguish in 10 minutes or less if left unattended. The bill, promoted by the furniture industry, was quickly killed in the US House of Representatives after swift and intense lobbying by the Tobacco Institute. The tobacco lobby went further: during the next six weeks, an amendment to the recently passed Consumer Product Safety Act specifically forbade the US Consumer Product Safety Commission from regulating cigarettes as a fire hazard.

In 1976, while attending a fire prevention conference sponsored by the US Fire Administration, I overheard a hallway conversation in which a fire marshal declared that "the best way to prevent fire deaths was to require cigarettes to self extinguish". I asked if he had evidence to support his claim. He said that he could not remember when or where he had heard about self extinguishing cigarettes but felt strongly that it was the best approach to prevent fires. Because he provided no evidence, I was intrigued enough to investigate his apparently wild claim. During the next two years, I researched the issue with minimal success. In the fall of 1978 I decided to enlist the talents of an investigative reporter Mark Dowie, who wrote the famous story on the explosion problem associated with Ford Pinto fuel tanks. I told Mark that it appeared that there was a larger fire death problem with cigarettes that could be prevented by making cigarettes self extinguish. Mark suggested I take the issue to the Center for Investigative Reporting (CIR). I met with the three founders of the Center (Dan Noyes, David Weir, and Lowell Bergman), provided them with the scant information I had collected, and brokered a grant from the local firefighters union to fund the investigation. The investigation was completed and published in the June 1979 issue of Mother Jones magazine.

Before publication, I launched a campaign calling on cigarette manufacturers to produce self extinguishing or, as they were subsequently named, "fire safe" cigarettes. In conjunction with the CIR and Mother Jones staff, I circulated preprints of the article and a press release to colleagues in 14 US cities. At each press event we released the story to the media, demanded that cigarette companies produce fire safe cigarettes, and announced that the American Burn Association and the International Association of Fire Chiefs endorsed the campaign. The event received national media coverage and marked the official beginning of a 27 year (and counting) campaign. Six days after the media launch, in Westwood, Massachusetts, a cigarette caused fire killed a husband 
and wife and their five children. In response, the Congressman representing Boston and Westwood, Joe Moakley, introduced legislation calling for fire safe cigarettes. The battle with the tobacco industry was launched.

\section{THE CAMPAIGN: 1980-2005}

The advocacy effort to regulate the cigarette industry for fire safety was inexorably slow and difficult. The battle was waged on five fronts: in the halls of Congress, in state legislatures, in the courts, in other countries, and, most importantly, in the media. It would be impossible to properly recount the 27 year period in this paper, but there are a few highlights and numerous individuals that deserve recognition. First, a brief summary of the five fronts.

\section{US Congress}

In March 1983 the first hearing on the Moakley bill was held in Congressman Henry Waxman's Subcommittee on Health and the Environment. The Senate version, introduced by Alan Cranston, was first heard in July 1983 in the Senate Select Committee on Aging. President Reagan signed an amended version of Moakley's bill, the Safe Cigarette Act, into law in August 1984. This act funded a three year, $\$ 3$ million research effort, overseen by a 15 member Technical Strategy Group (TSG), that was primarily conducted at the NBS' Center for Fire Research (appendix l; see http://injuryprevention. com/supplemental for details).

The Act required the TSG to report to Congress whether or not it was technically and economically feasible for the cigarette industry to produce a fire safe cigarette (or, in technical terms, a "reduced ignition propensity cigarette"). All 15 members of the TSG, including the four representatives from cigarette companies, concluded that it was.

Congressman Moakley introduced the next Fire Safe Cigarette bill in January 1988. This bill was signed into law the following October. The TSG was reconvened (now renamed the Technical Advisory Group (TAG)) to oversee an additional three years of research to develop a fire safety test method that could be used by regulatory bodies to promulgate a performance standard for cigarettes. In other words, a measuring tool had to be developed to ascertain whether a cigarette was "fire safe". A test method was developed and, nearly eight years later, slightly modified and improved by ASTM.

In April 2005 two US Representatives (Markey and King) introduced the National Cigarette Fire Safety Legislation. If passed, this law would mandate a national safety performance standard for all cigarettes sold and manufactured in the US. As of the writing of this article no federal hearings on this file have been scheduled.

\section{State legislation}

The first state bill calling for fire safe cigarettes was introduced in Oregon in late 1979. Since then 19 other state bills have been introduced and often reintroduced (see appendix 2; http:// injuryprevention.com/supplemental for details) At present, California and Massachusetts may soon join New York and Vermont as the only states mandating the sale of fire safe cigarettes. The New York effort was led by Assemblyman Pete Grannis with the support of numerous advocates, including New York Public Interest Research Group's Russ Haven, New York City Fire Department's Kevin James, New York tobacco control advocate Russ Sciandra, and hundreds of others from the volunteer fire service in NY state. With the New York bill becoming law on 16 August 2000 and the performance standard promulgation on 28 June 2004, it became politically feasible to lobby other state legislatures.

The Harvard School of Public Health issued a report entitled 'Fire Safer' Cigarettes: the Effect of the New York State Cigarette Fire Safety Standard on Ignition Propensity, Smoke Toxicity and the Consumer Market (January 2005). This report evaluated the various effects of the first six months of the New York standard. It concluded that, although a reduction in cigarette related fires, deaths, and injuries was too early to detect (typically, fire data are not collected and provided to researchers or the general public until two years later), it was clear that the law was being complied with, that sales of cigarettes were not affected, and that the toxicity levels of the "new" cigarettes were roughly equivalent with that of other cigarettes.

The importance of the state legislative efforts can not be overstated. The state efforts have generated, in some instances, national media coverage. Additionally, hundreds of organizations and thousands of advocates and supporters have united in fighting the well financed defensive efforts of the tobacco industry. Because there is no federal preemption of state law in the cigarette fire safety arena, the state lobbying efforts have been able to proceed-with ultimate success.

\section{Lawsuits}

Numerous product liability suits have been filed against cigarette manufacturers since the first such suit in 1979 in Los Angeles filed by attorney Joel
Kleinberg. The general theory in these cases is that because the cigarette manufacturers know how to produce a fire safe product, the manufacturer should be held liable for the costs, pain, and suffering of fires caused by their products. The issue of technical feasibility was in question until the TSG reported its results in 1987. Commercial feasibility was demonstrated when Philip Morris produced and sold a fire safe version of their Merit brand in 2001. The first suit "settled out of court", (the previously referred to Shannon Moore case) signaled the legal community that there are grounds for future suits to compensate victims and survivors and to punish cigarette companies for their decades-long delay in bringing fire safety to the marketplace. Proof of that delay was provided in 1987 when I was asked to be an expert consultant on a products liability suit filed against Philip Morris in New Jersey State court. Although I was instructed by the court not to discuss or show the documents to anyone, I broke the protective order and gave the documents to 60 Minutes. The documents provided clear evidence that by mid1987 Philip Morris had conducted consumer test panels using a fire safe cigarette that was indistinguishable from their best selling cigarette, Marlboro. The eight year research effort at Philip Morris was given the secret code name "Project Hamlet". During the discovery phase of the case when a Philip Morris researcher was asked what the code name meant, she replied, "It was named Project Hamlet; you know, to burn or not to burn". Outside of Philip Morris, this is not funny.

Attorney Doug Lennox filed a Canadian class action suit targeting Imperial Tobacco Canada Ltd in January 2000 as a result of a cigarette fire in January 1998 that killed three children. Justice Cullity of the Ontario Superior Court stated that the class action suit should be heard. Worldwide, this is the first certified class action suit that seeks to represent all Canadians who were burned or died in cigarette fires since 1987. A settlement will lead to redistribution of financial liability; currently, the cost of these burn deaths, injuries, and property damage is borne by the public or individuals through insurance premium payments or out of pocket payments. In the US, only a small portion of the financial damage caused by cigarette companies has been recouped by a massive settlement engineered by states' Attorney Generals. The specific cost burden of cigarette caused fires remains partially hidden. A successful class action suit will highlight the industry's 
corporate behavior-behavior that includes well documented decisions to withhold safety technology knowing that its customers would die or burn in cigarette caused fires; behavior that is clearly criminal.

\section{Canada and other nations}

In 2004 Bill C-260 (an Act to amend the Hazardous Products Act (fire safe cigarettes) authored by John McKay) was passed in the House of Commons. Dr Yves Morin sponsored the successful companion bill in the Senate. It became law in March 2004. The final regulation was announced in May 2005 and will take effect throughout Canada on 1 October 2005. Numerous advocates in Canada promoted this legislation for over 20 years including the fire service, burn care centers, and the Nonsmokers' Rights Association.

Other nations now considering such legislation include Taiwan, Japan, Australia, New Zealand, South Africa, Great Britain, Poland, and other European nations.

\section{Media: the advocates' ally}

Without media coverage there would not have been success in New York or Canada. Two ingredients are necessary when engaging in injury control campaigns that are opposed by well financed opponents. The first is a clear and flexible media strategy. The second is a large list of contact information for journalists, news producers, assignment editors, and so on.

The media strategy for the fire safe cigarette campaign was simple and inexpensive. I asked colleagues and friends in the "burn world" (burn survivors and their families, surgeons, nurses, and other members of the burn care team represented by the Phoenix Society and the American Burn Association), in the fire service (unions, fire marshals, fire chiefs represented by the IAFF, IAFC, and the National Fire Protection Association), and others who were sympathetic to alert me to any cigarette caused fire deaths if the fire occurred in their city or town. Once I received a call from a local contact (in the 1990s emails replaced phone calls) I prepared a press release stating that the fatality could have been prevented if the pending federal (or state) bill were enacted. I sent this release to the local contact who would edit the release and declare to the local media that he or she was leading the effort calling for the passage of legislation. After a while, the tobacco industry did not know who was directing the media campaign. Almost without exception, there was local coverage of the issue, and occasionally national coverage, especially if there were multiple deaths of children caught in the fire. Over the years, the national and international coverage accrued to the point that the tobacco industry could no longer stop the effort. This media strategy was connected to numerous other advocacy strategies (for example, coalition building, letter writing campaigns, direct lobbying of legislators) but the potency of the coverage set the stage for legislative successes.

Although I have met or corresponded with hundreds of journalists, two of the most important contacts were a former producer for 60 Minutes, Lowell Bergman, and an investigative reporter with the Los Angeles Times, Myron Levin.

As mentioned earlier, I met Lowell at CIR in 1978 before he went to work for 60 Minutes. Years later, in 1994, Lowell produced a story on fire safe cigarettes for 60 Minutes. During the making of the piece, I convinced the "tobacco whistleblower", Jeffrey Wigand, to meet Lowell and serve as a technical consultant on the fire safe cigarette story. Wigand came to trust Lowell and, ultimately, told what he knew about the tobacco industry to 60 Minutes. The film, The Insider, is based on these events. Ironically, it is little known that Wigand was hired in the late 1980s to head Research and Development for Brown and Williamson Tobacco Company to create, among other tasks, a fire safe cigarette. He has subsequently served as a scientific expert worldwide on the fire safe cigarette technology alongside other tobacco related issues.

Besides front page stories in the Los Angeles Times, Levin has written a landmark investigative story on the fire safe cigarette issue published in the Nation in 1988. It detailed the massive lobbying effort of the Tobacco Institute to derail US fire service support for fire safe cigarette legislation. In the recent past, tobacco documents that were "discovered" in the lawsuits filed by the Attorney Generals have been made searchable by keyword. A quick search of "fire safe cigarettes" yields extensive corroborations of Levin's work as well as that of other journalists who have covered this story.

\section{TRAGEDY}

The generation-long campaign for fire safe cigarettes is nearing the concluding act. The universal production of fire safe cigarettes will be inevitable because of precedent setting efforts in New York State and Canada. The only safer solution is the elimination of all smoking. The corporate generated tragedy is beyond contemplation: since the time when the technology was available for the manufacturers to produce fire safe cigarettes, the number of fire deaths and burn injuries that should never have occurred is approaching 300000 in the US alone. Worldwide the tragedy expands to ghoulish dimensions.

Injury Prevention 2005;11:264-266. doi: 10.1136/ip.2005.009936

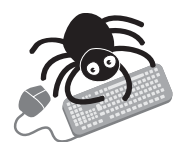

Appendices 1 and 2 are available on our website: http://injuryprevention. com/supplemental

Correspondence to: Mr A McGuire, Trauma Foundation, San Francisco General Hospital, San Francisco, CA 94110, USA; am@if.org

Accepted 24 July 2005

Fire Safe Cigarettes advocates' website: http:// www.firesafecig.org

\section{1 th European Forum on Quality Improvement in Health Care}

26-28 April 2006, Prague, Czech Republic

For further information please go to: www.quality.bmjpg.com

Book early to benefit from a discounted delegate rate 